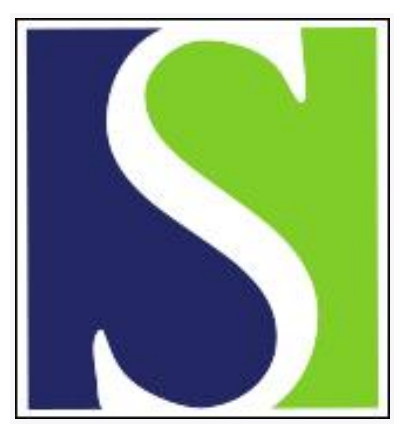

Scand J Work Environ Health 1983;9(2):108-114

https://doi.org/10.5271/sjweh.2436

Issue date: Apr 1983

Genetic toxicity of styrene and some of its derivatives.

by Norppa $\mathrm{H}$, Vainio $\mathrm{H}$

This article in PubMed: www.ncbi.nlm.nih.gov/pubmed/6648407

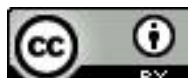

This work is licensed under a Creative Commons Attribution 4.0 International License 


\title{
Genetic toxicity of styrene and some of its derivatives
}

\author{
by Hannu Norppa, PhD, Harri Vainio, MD ${ }^{\prime}$
}

\begin{abstract}
NORPPA H, VAINIO H. Genetic toxicity of styrene and some of its derivatives. Scand $j$ work environ health 9 (1983) 108-114. Styrene, an important plastic monomer, is mutagenic after metabolic activation in several test systems. Probably because of an unfavorable activation : inactivation ratio, some mutagenicity assays have not, however, found styrene mutagenic. Styrene is converted by microsomal monooxygenases in vivo to styrene-7,8-oxide, which is a well-known mutagen. Arene oxides have also been proposed as the reactive metabolites of styrene, but the significance of these compounds is not yet fully understood. Only few derivatives of styrene have been tested for mutagenicity. The results are characterized by difficulties in metabolic activation. Many styrene-7,8-oxide analogues substituted at the phenyl ring are electrophilic reactants and mutagenic in vitro. Human whole-blood lymphocyte cultures have a peculiar feature, ie, styrene and many of its analogues substituted at the ring or vinyl chain induce sister chromatid exchanges in the cultured cells without exogenous metabolizing systems. This activation is brought about by erythrocytes present in the cultures and probably results from the conversion of styrenes to styrene-7,8-oxides.
\end{abstract}

Key terms: erythrocytes, human lymphocyte cultures, mutagenicity, sister chromatid exchanges, styrene oxide.

Styrene is a commercially important chemical used mainly in the production of polymers and reinforced plastics. It is an analogue of two carcinogens, benzene and vinyl chloride. Thus the toxicology and metabolism of styrene have been studied extensively [see the report of Vainio et al (31)].

In mammals and man styrene-7,8-oxide seems to be the key intermediate in the metabolic pathway that eventually leads to the main urinary metabolites of styrene, mandelic acid and phenylglyoxylic acid. Styrene-7,8-oxide is an alkylating agent and has been reported to be a carcinogen in rodents (31). Arene oxides are another group of reactive compounds suggested to be involved in styrene metabolism leading to phenolic metabolites in the urine. In humans this metabolic route seems to be, on the basis of the amount of 4-vinyl-

1 Department of Industrial Hygiene and Toxicology, Institute of Occupational Health, Helsinki, Finland.

Reprint requests to: $\mathrm{Dr} H$ Norppa, Institute of Occupational Health, Haartmaninkatu 1, SF00290 Helsinki 29, Finland. phenol in the urine, of minor importance (21).

Genotoxically styrene-7,8-oxide is likely to be the most important metabolite of styrene. However, the small contribution of ring-hydroxylation products in the urine does not necessarily mean that arene oxides would have no significance. Such compounds are actually very reactive (35). Nevertheless, the role of arene oxides in the genetic toxicology of styrene is not yet fully understood.

In this communication we present a review on the mutagenicity of styrene, styrene oxides, and some of their derivatives. We also discuss our latest findings on the induction of chromosome damage by styrene and analogues in human lymphocyte cultures. This test system differs from most others because of the clear response to styrene without any exogenous metabolizing systems.

\section{Mutagenicity in bacteria}

Styrene-7,8-oxide is a potent mutagen in bacteria (table 1 ). It is mutagenic to 
Table 1. Mutagenicity of styrene oxides and styrenes in bacteria. $(+=$ results positive, $-=$ results negative, $\pm=$ both positive and negative results reported, $\cdots=$ data unavailable)

\begin{tabular}{|c|c|c|c|c|c|}
\hline \multirow{2}{*}{$\begin{array}{l}\text { Compound } \\
\text { and substituents }\end{array}$} & \multicolumn{2}{|c|}{$\begin{array}{l}\text { Salmonella } \\
\text { typhimurium }\end{array}$} & \multirow{2}{*}{$\begin{array}{c}\text { Escherichia } \\
\text { coli } \\
\text { (no acti- } \\
\text { vation) }\end{array}$} & \multirow{2}{*}{$\begin{array}{l}\text { Klebsiella } \\
\text { pneumoniae } \\
\text { (no acti- } \\
\text { vation) }\end{array}$} & \multirow{2}{*}{ References } \\
\hline & $\begin{array}{l}\text { No } \\
\text { metabolic } \\
\text { activation }\end{array}$ & $\begin{array}{l}\text { Metabolic } \\
\text { activation }\end{array}$ & & & \\
\hline Styrene-7,8-oxide & + & + & + & + & $\begin{array}{l}\text { Sugiura \& Goto (25), Sugiura } \\
\text { et al (26), Vainio et al (32), } \\
\text { Watabe et al (35) [see Norppa } \\
\text { (13), Vainio et al (31)] }\end{array}$ \\
\hline 3-bromo & + & . & $\cdots$ & $\cdots$ & Jung et al (8) \\
\hline 3-chloro & + & . & + & $\cdots$ & Sugiura \& Goto (25) \\
\hline 3-methyl & . & . & + & . & Sugiura \& Goto (25) \\
\hline 3-methoxy & . & . & + & . & Sugiura \& Goto (25) \\
\hline 4-bromo & + & . & + & . & $\begin{array}{l}\text { Jung et al (8), Sugiura \& } \\
\text { Goto (25) }\end{array}$ \\
\hline 4-chloro & + & . & . & . & Sugiura et al (26) \\
\hline 4-methyl & + & . & + & .. & Sugiura \& Goto (25) \\
\hline 4-phenyl & + & . & . & . & Jung et al (8) \\
\hline 3,4-dimethyl & . & . & + & . & Sugiura \& Goto (25) \\
\hline$\alpha$-methyl & - & . & . & . & Wade et al (34) \\
\hline$\alpha$-phenyl & 一 & . & . & - & $\begin{array}{l}\text { Jung et al (8), Voogd et al } \\
\text { (33), Wade et al (34) }\end{array}$ \\
\hline trans- $\beta$-methyl & - & . & $\cdots$ & $\cdots$ & EJ-Tantawy \& Hammock $(7)$ \\
\hline trans- $\beta$-phenyl & - & . & . & 一 & $\begin{array}{l}\text { Voogd et al (33), Wade et } \\
\text { al (34) }\end{array}$ \\
\hline $\begin{array}{l}\operatorname{trans}-\beta-(4-a c e t y l- \\
\text { aminophenyl) }\end{array}$ & - & $\cdots$ & . & . & Wade et al (34) \\
\hline cis- $\beta$-phenyl & + & . & $\cdots$ & $\cdots$ & Wade et al (34) \\
\hline $\begin{array}{l}\text { cis- } \beta \text {-(4-acetyl- } \\
\text { aminophenyl) }\end{array}$ & - & $\cdots$ & . & . & Wade et al (34) \\
\hline $\begin{array}{l}\beta \text {-carboxylic acid } \\
\text { ethyl ether a }\end{array}$ & + & + & . & - & Voogd et al (33) \\
\hline $\begin{array}{l}\alpha \text {-methyl, } \\
\beta \text {-carboxylic acid } \\
\text { ethyl ether a }\end{array}$ & 一 & - & . & - & Voogd et al (33) \\
\hline Styrene-1,2-oxide & + & $\cdots$ & . & . & Watabe et al (35) \\
\hline Styrene-3,4-oxide & + & + & $\cdots$ & . & Watabe et al (35) \\
\hline Styrene & - & \pm & $\cdots$ & $\cdots$ & $\begin{array}{l}\text { De Meester et al (6), Vainio } \\
\text { et al (32) [see Norppa (13), } \\
\text { Vainio et al (31)] }\end{array}$ \\
\hline $\begin{array}{l}\text { 3- and 4-methyl } \\
\text { (mixed isomers) }\end{array}$ & - & - & $\cdots$ & . & Norppa et al (17) \\
\hline 4-phenyl & - & - & $\cdots$ & . & Simmon \& Baden (23) \\
\hline $\begin{array}{l}a \text {-(4-chlorophenyl)- } \\
\text { 4-chloro }\end{array}$ & - & - & . & $\cdots$ & Planche et al (22) \\
\hline $\begin{array}{l}\text { trans- } \beta \text {-aldehyde } \\
\text { trans- } \beta \text {-carboxylic } \\
\text { acid }\end{array}$ & $\ldots$ & - & . & . & $\begin{array}{l}\text { Lijinsky \& Andrews (11) } \\
\text { Lijinsky \& Andrews (11) }\end{array}$ \\
\hline $\begin{array}{l}\text { 4-methoxy-trans- } \\
\beta \text {-methyl }\end{array}$ & + & + & $\cdots$ & . & Swanson et al (28) \\
\hline $\begin{array}{l}\text { 4-methoxy-trans- } \\
\beta \text {-hydroxymethyl }\end{array}$ & - & + & . & . & Swanson et al (28) \\
\hline
\end{tabular}

a Isometer not indicated in the report. 
bacteria strains that detect base-pair substitutions, but not to strains detecting frameshift mutations. This phenomenon also occurs for several styrene-7,8-oxide analogues substituted at the phenyl ring (table 1). However the few studies of derivatives with a substituent at the side chain have been mainly negative.

Two possible arene oxide intermediates of styrene, styrene-1,2-oxide and styrene3,4-oxide, were recently reported to be more mutagenic in Salmonella typhimurium than the 7,8-oxide, but only after sequential dosing, which illustrates the high lability of the arene oxides (35). There are no other studies on the mutagenicity of styrene-1,2-oxide or styrene3,4-oxide, and these intermediates will not be discussed further.

The results on the mutagenicity of styrene in Salmonella have been contradictory. After the first, positive, report by Vainio and co-workers (32), in the presence of metabolic activation, both confirming and deviating results have been published (table 1). Microbial assays on styrene are complicated by the fact that the mutagenic concentration range when found - is narrow (6). Another problem is the ratio of activation and inactivation in microsomal metabolizing systems, which often seems to be unfavorable for the metabolic activation of styrene (2). Similar kinds of difficulties probably exist with bacterial mutagenicity tests with some analogues of styrene (table 1), of which only 4-methoxy-trans$\beta$-methylstyrene and its hydroxy derivative have been found to be mutagenic.

\section{Mutagenicity in nonmammalian eucaryotic systems}

Styrene-7,8-oxide has been reported to induce point mutations in yeasts, chromosome damage in plants, and recessive lethal mutations in Drosophila melanogaster (30) [see also the reports of Norppa (13) and Vainio et al (31)]. Styrene has shown mutagenic activity in the host-mediated assay on Saccharomyces cerevisiae with mouse as the host, in the induction of chromosome damage in Allium cepa, and in the recessive lethal test in Drosophila $(13,31)$. The in vitro assays with yeasts seem to have difficulties similar to those incurred with the bacterial tests in the metabolic activation of styrene by microsomal preparations (2).

Knowledge on the mutagenicity of styrene derivatives in nonmammalian eucaryotic test systems is scanty. Only vinyltoluene has been tested in Drosophila, with negative results (17).

\section{Mutagenicity in mammalian cells in vitro}

Table 2 shows that styrene-7,8-oxide induces point mutations, chromosome aberrations, micronuclei, sister chromatid exchanges, and unscheduled DNA (deoxyribonucleic acid) synthesis in cultured mammalian cells. In rat hepatocytes and in a liver perfusion system with V79 cells as indicators, styrene-7,8-oxide seems to be inactivated efficiently. Some analogues of styrene-7,8-oxide have also been reported to induce point mutations in V79 cells.

Styrene has been positive in point mutation induction in V79 cells with the liver perfusion system and in the chromosome aberration test in CHL cells in the presence of S-9 mix. A negative result has been reported for point mutations in V79 cells, irrespective of the use of S-9 mix, and for unscheduled DNA synthesis in human EUE cells in the presence of S-10 mix. In CHO cells, an inhibitor of epoxide hydrolase (cyclohexene oxide) is needed, in addition to S-9 $\mathrm{mix}$, for a positive response in sister chromatid exchanges (table 2). One analogue of styrene - 4-hydroxystyrene-trans- $\beta$ carboxylic acid - has been shown to induce chromosome aberrations in $\mathrm{CHO}$ cells in the presence of metabolic activation (table 2).

\section{Chromosome damage in rodents in vivo}

In vivo studies on the chromosome damaging effects of styrene and styrene-7,8oxide on rodents have given contradictory results $(9,14)$ [see also the reports of Norppa (13) and Vainio et al (31)]. With the exception of one study on styrene in rats, all positive results for either of the compounds have been obtained in mice. This finding probably reflects metabolic 
differences between species. Mice have a low activity of microsomal epoxide hydrolase, the enzyme capable of inactivating styrene-7,8-oxide.

To our knowledge, the only styrene analogue tested with a mammalian in vivo test is vinyltoluene, which was able to induce micronuclei in mice (14).

\section{Chromosome damage in workers exposed to styrene}

Cytogenetic studies on workers exposed to styrene have recently been reviewed (13, $19,31,36$ ). Increased frequencies of chromosome aberrations have been seen in lymphocytes of workers employed in the reinforced plastics industry, mainly in manual laminating jobs, where exposure to styrene is high. Studies of workers in the production of styrene or polystyrene have been negative. The difference between these branches of industry probably reflects differences in exposure levels.

Two studies have also reported an increase of micronuclei in the lymphocytes of workers from the reinforced plastics industry. Results on sister chromatid exchanges among styreneexposed workers have been positive in one study, but negative in others $(13,19,31$, 36).

\section{Chromosome damage in human lymphocytes in vitro}

The preceding review shows that the metabolic activation of styrene is problematic in most mutagenicity test systems. Human whole-blood lymphocyte cultures differ from all other assay systems in response to styrene; a clear dose-dependent increase is seen in sister chromatid exchanges after treatment of these cultures with styrene, without the use of any exogenous metabolizing systems (18). Such an increase also occurs for many analogues of styrene (table 3). Furthermore styrene has been reported to induce chromosome aberrations and micronuclei in cultured lymphocytes (table 3 ). These results can be explained only by the conversion of styrenes into an active form in the cultures.

It is probable that styrenes are converted into styrene-7,8-oxides in the lymphocyte cultures. This statement is supported by many observations: (i) styrene-7,8-oxide and some of its ring-substituted analogues are able to produce chromosome damage in cultured lymphocytes (table 3); (ii) gas chromatographically measurable amounts of styrene-7,8-oxide are generated in cultures treated with styrene (18); (iii) styrene derivatives without a double

Table 2. Mutagenicity of styrene oxides and styrenes in mammalian cell cultures (excluding human lymphocytes). (DNA $=$ deoxyribonucleic acid, $+=$ results positive, $-=$ results negative, $\cdots=$ data unavailable)

\begin{tabular}{|c|c|c|c|c|c|c|c|c|c|c|}
\hline \multirow{3}{*}{$\begin{array}{l}\text { Compound } \\
\text { and } \\
\text { substituents }\end{array}$} & \multicolumn{9}{|c|}{ Test system } & \multirow{3}{*}{ References } \\
\hline & \multicolumn{2}{|c|}{ Point mutations } & \multicolumn{2}{|c|}{$\begin{array}{l}\text { Chromosome } \\
\text { aberrations }\end{array}$} & \multirow{2}{*}{$\begin{array}{l}\text { Micro- } \\
\text { nuclei } \\
\text { (no act- } \\
\text { ivation) }\end{array}$} & \multicolumn{2}{|c|}{$\begin{array}{l}\text { Sister chromatid } \\
\text { exchange }\end{array}$} & \multicolumn{2}{|c|}{$\begin{array}{l}\text { Unscheduled } \\
\text { DNA synthesis }\end{array}$} & \\
\hline & $\begin{array}{l}\text { No act- } \\
\text { ivation }\end{array}$ & $\begin{array}{l}\text { Act- } \\
\text { ivation }\end{array}$ & $\begin{array}{l}\text { No act- } \\
\text { ivation }\end{array}$ & $\begin{array}{l}\text { Act- } \\
\text { ivation }\end{array}$ & & $\begin{array}{l}\text { No act- } \\
\text { ivation }\end{array}$ & $\begin{array}{l}\text { Act- } \\
\text { ivation }\end{array}$ & $\begin{array}{l}\text { No act- } \\
\text { ivation }\end{array}$ & $\begin{array}{l}\text { Act- } \\
\text { ivation }\end{array}$ & \\
\hline Styrene-7,8-oxide & + & $-\mathbf{a}$ & + & .. & + & + & + & + & $-b$ & $\begin{array}{l}\text { Amacher \& Turner }(1) \text {, } \\
\text { Beije \& Jenssen }(3) \text {, } \\
\text { Brouns et al (5), } \\
\text { Kubiak et al (10), } \\
\text { Sugiura et al }(27) \text {, } \\
\text { Turchi et al (29) [see } \\
\text { Norppa (13), Vainio } \\
\text { et al (31)] }\end{array}$ \\
\hline 3-chloro & + & . & $\cdots$ & .. & .. & . & $\cdots$ & $\cdots$ & $\cdots$ & Sugiura et al (27) \\
\hline 4-methyl & + & . & . & .. & . & - & .. & .. & $\cdots$ & Sugiura et al (27) \\
\hline 3,4-dimethyl & + & $\ldots$ & .. & . & . & . & $\cdots$ & . & .. & Sugiura et al (27) \\
\hline Styrene & - & $-+^{a}$ & 一 & + & $\cdots$ & - & $+c$ & 一 & 一 & $\begin{array}{l}\text { Beije \& Jenssen (3), } \\
\text { Kawachi et al (9) [see } \\
\text { Norppa (13), Vainio } \\
\text { et al (31)] }\end{array}$ \\
\hline $\begin{array}{l}\text { 4-hydroxy, trans- } \beta \text { - } \\
\text { carboxylic acid }\end{array}$ & .. & $\cdots$ & 一 & + & $\cdots$ & $\cdots$ & $\cdots$ & . & $\cdots$ & Stich (24) \\
\hline
\end{tabular}

a In V79 cells with a liver perfusion system.

$b$ In isolated rat hepatocytes.

c Only with cyclohexene oxide present. 
Table 3. Induction of chromosome damage by styrene oxides and styrenes in human whole-blood lymphocyte cultures. $(+=$ results positive, $-=$ results negative, $(+)=$ a marginal positive effect only at one concentration, $\cdots=$ data unavailable)

\begin{tabular}{|c|c|c|c|c|}
\hline $\begin{array}{l}\text { Compound } \\
\text { and substituents }\end{array}$ & $\begin{array}{c}\text { Sister } \\
\text { chromatid } \\
\text { exchanges }\end{array}$ & $\begin{array}{c}\text { Chromosome } \\
\text { aberrations }\end{array}$ & Micronuclei & References \\
\hline Styrene-7,8-oxide & + & + & + & $\begin{array}{l}\text { Norppa et al (16), Norppa et al (18) } \\
\text { [see Norppa (13), Vainio (31)] }\end{array}$ \\
\hline 4-methyl & $+a$ & $\cdots$ & $\cdots$ & Norppa (13), Norppa \& Vainio (15) \\
\hline 4-nitro & + & . & . & Norppa (13), Norppa \& Vainio (15) \\
\hline 3,5-dimethyl & + & $\cdots$ & .. & Norppa \& Vainio (15) \\
\hline Styrene & + & + & + & $\begin{array}{l}\text { Norppa et al (18) [see Norppa (13), } \\
\text { Vainio (31)] }\end{array}$ \\
\hline 2-methyl & + & . & . & Norppa \& Vainio (15) \\
\hline 3-methyl & + & $\cdots$ & . & Norppa \& Vainio (15) \\
\hline 4-methyl & + & + & . & Norppa (13), Norppa \& Vainio (15) \\
\hline $\begin{array}{l}3-\text { and 4-methyl } \\
\text { (mixed isomers) }\end{array}$ & + & + & $\cdots$ & Norppa (12) \\
\hline 3,5-dimethyl & + & . & . & Norppa \& Vainio (15) \\
\hline$\alpha$-methyl & $+a$ & $\cdots$ & . & Norppa (13), Norppa \& Vainio (15) \\
\hline trans- $\beta$-methyl & + & . & $\cdots$ & Norppa \& Vainio (15) \\
\hline $\begin{array}{l}\text { trans- } \beta \text {-nitro } \\
\text { 4-methoxy-trans- }\end{array}$ & $-b$ & $-b$ & . & Norppa (12) \\
\hline$\beta$-chloro & $+c$ & $+c$ & . & Norppa (12) \\
\hline Ethylbenzene & $(+)$ & . & $\cdots$ & Norppa \& Vainio (15) \\
\hline 2-Phenylethanol & - & $\cdots$ & . & Norppa \& Vainio (15) \\
\hline
\end{tabular}

a No doubling of the mean number of sister chromatid exchanges/cell observed.

b Too toxic to be properly evaluated.

c Active within a lower concentration range than styrene.

bond in the side chain are negative or almost negative in sister chromatid exchange induction [2-phenylethanol and ethylbenzene (15)]; (iv) styrenes methylated at the ring induce a clear dose-response in sister chromatid exchanges, while substitution of the side chain seems to modify the effect (15); (v) finally, both human lymphocytes and erythrocytes are able to convert styrene into styrene-7,8-oxide (4.)

Whole-blood lymphocyte cultures, which have been used in our studies, contain all the cell types present in normal blood. Thus any of these cell populations may be responsible for the metabolic activation of styrene in such cultures. The studies of Belvedere \& Tursi (4) indicate that, although lymphocytes are more efficient in the metabolic conversion of styrene into styrene-7,8-oxide, erythrocytes are much more important in whole blood because of their high number. Actually, our recent results show that, if erythrocytes are removed before cultivation, no clear effect on sister chromatid exchanges is obtained with styrene treatment (20). Furthermore the mean number of sister chromatid exchanges, after a fixed dose of styrene, is dependent on the number of erythrocytes present in the cultures.

It is thus evident that the difference in response to styrene between the lymphocyte system and other mutagenicity assays is due to red blood cells present in the whole blood cultures. We do not yet know what the role of erythrocytes is in the induction of chromosome damage in the lymphocytes of workers exposed to styrene. Certainly the unexpected involvement of red blood cells in the metabolism of styrene opens many questions.

\section{References}

1. Amacher DE, Turner GN. Mutagenic evaluation of carcinogens and non-carcinogens in the L5178Y/TK assay utilizing postmitochondrial fractions (S9) from 
normal rat liver. Mutat res 97 (1982) 4965.

2. Bauer C, Leporini C, Bronzetti G, Corsi C, Nieri R, Del Carratore R, Tonarelli S. The problem of negative results for styrene in the in vitro mutagenesis test with metabolic activation (microsomal assay): Explanation by gas chromatographic analysis. Boll soc ital biol sper 56 (1980) 203-207.

3. Beije B, Jenssen D. Investigation of styrene in the liver perfusion/cell culture system: No indication of styrene-7,8-oxide as the principal mutagenic metabolite produced by the intact rat liver. Chem biol interact 39 (1982) $57-76$.

4. Belvedere G, Tursi F. Styrene oxidation to styrene oxide in human blood erythrocytes and lymphocytes. Res commun chem pathol pharmacol 33 (1981) 273-282.

5. Brouns RE, Poot M, de Vrind R, v HoekKon T, Henderson PT, Kuyper CMA. Measurement of DNA-excision repair in suspensions of freshly isolated rat hepatocytes after exposure to some carcinogenic compounds: Its possible use in carcinogenicity screening. Mutat res 64 (1979) $425-432$.

6. De Meester $\mathrm{C}$, Duverger-van Bogaert $\mathrm{M}$, Lambotte-Vandepaer M, Mercier M, Poncelet F. Mutagenicity of styrene in the Salmonella typhimurium test system. Mutat res 90 (1981) $443-450$.

7. El-Tantawy MA, Hammock BD. The effect of hepatic microsomal and cytosolic subcellular fractions on the mutagenic activity of epoxide-containing compounds in the Salmonella assay. Mutat res 79 (1980) 59-71.

8. Jung $R$, Glatt $H R$, Beerman $D$, Oesch $F$. Mutagenicity of epoxides. Mutat res 74 (1980) 210.

9. Kawachi T, Yahagi $T$, Kada T, Tazima $Y$, Ishidate M, Sasaki M, Sugiyama T. Cooperative programme on short-term assays for carcinogenicity in Japan. In: Monesano R, Bartsch $\mathrm{H}$, Tomatis L, Davis W, ed. Molecular and cellular aspects of carcinogen screening tests. International Agency for Research on Cancer, Lyon 1980, pp $323-330$. (Scientific publication no 27).

10. Kubiak $R$, Linnainmaa $K$, Norppa $H$, Sorsa M. SCE responses in CHO cells induced by some monosubstituted epoxides. Mutat res 97 (1982) 199.

11. Lijinsky W, Andrews AW. Mutagenicity of vinyl compounds in Salmonella typhimurium. Teratogenesis carcinog mutagenesis 1 (1980) 259-267.

12. Norppa $\mathrm{H}$. The in vitro induction of sister chromatid exchanges and chromosome aberrations in human lymphocytes by styrene derivatives. Carcinogenesis 2 (1981) $237-242$.

13. Norppa H. Chromosome damage induced by styrene, styrene oxide and some analogues. Doctoral dissertation. Institute of Occupational Health and University of Helsinki, Helsinki 1981.

14. Norppa H. Styrene and vinyltoluene induce micronuclei in mouse bone marrow. Toxicol lett 8 (1981) 247-251.

15. Norppa $H$, Vainio $H$. Induction of sisterchromatid exchanges by styrene analogues in cultured human lymphocytes. Mutat res 116 (1983) $379-387$.

16. Norppa $H$, Hemminki $K$, Sorsa M, Vainio H. Effect of monosubstituted epoxides on chromosome aberrations and SCE in cultured human lymphocytes. Mutat res 91 (1981) $243-250$.

17. Norppa H, Skyttä E, Donner M, Sorsa M, Vainio $\mathrm{H}$. Mutagenicity of vinyl toluene. Mutat res 85 (1981) 294.

18. Norppa H, Sorsa M, Pfäffli P, Vainio $H$. Styrene and styrene oxide induce SCEs and are metabolised in human lymphocyte cultures. Carcinogenesis 1 (1980) 357-361.

19. Norppa H, Vainio H, Sorsa M. Commentary: Chromosome aberrations in lymphocytes of workers exposed to styrene. Am $j$ ind med 2 (1981) 299-304.

20. Norppa $H$, Vainio $H$, Sorsa $M$, Belvedere G. Metabolic activation of styrene by erythrocytes in human lymphocyte cultures. In: 12th annual meeting of European Environmental Mutagen Society, Espoo June 20-24, 1982: Abstracts. Institute of Occupational Health, Helsinki $1982, \mathrm{p} 148$.

21. Pfäffli P, Hesso A, Vainio $H$, Hyvönen $M$. 4-Vinylphenol excretion suggestive of arene oxide formation in workers occupationally exposed to styrene. Toxicol appl pharmacol 60 (1981) 85-90.

22. Planche G, Croisy A, Malaveille C, Tomatis L, Bartsch H. Metabolic and mutagenicity studies on DDT and 15 derivatives: Detection of 1,1-bis( $p$-chlorophenyl)-2,2dichloroethane and 1,1-bis( $p$-chlorophenyl)2,2,2-trichloroethyl acetate (kelthane acetate) as mutagens in Salmonella typhimurium and of 1,1-bis(p-chlorophenyl)ethylene oxide, a likely metabolite, as an alkylating agent. Chem biol interact 25 (1979) 157-175.

23. Simmon VF, Baden JM. Mutagenic activity of vinyl compounds and derived epoxides. Mutat res 78 (1980) 227-231.

24. Stich $\mathrm{HF}$, Rosin MP, Wu CH, Powrie WD. The action of transition metals on the genotoxicity of simple phenols, phenolic acids and cinnamic acids. Cancer lett 14 (1981) $251-260$.

25. Sugiura K, Goto M. Mutagenicities of styrene oxide derivatives on bacterial test systems: Relationship between mutagenic potencies and chemical reactivity. Chem biol interact 35 (1981) $71-91$.

26. Sugiura K, Kimura T, Goto M. Mutagenicities of styrene oxide derivatives on Salmonella typhimurium (TA 100): Relationship between mutagenic potencies and chemical reactivity. Mutat res 58 (1978) $159-165$.

27. Sugiura K, Maeda A, Goto M. Substitutional effects of styrene oxides on survival and mutation induction in cultured Chinese hamster cells (V-79). Chemosphere 8 (1979) $369-372$. 
28. Swanson AB, Chambliss DD, Blomquist JC, Miller EC, Miller JA. The mutagenicities of safrole, estragole, eugenol, trans-anethole, and some of their known or possible metabolites for Salmonella typhimurium mutants. Mutat res 60 (1979) 143-153.

29. Turchi G, Bonatti S, Citti L, Gervasi PG, Abbondandolo, A, Presciuttini S. Alkylating properties and genetic activity of 4vinylcyclohexene metabolites and structurally related epoxides. Mutat res 83 (1981) $419-430$.

30. Turchi G, Bonatti S, Nuti Ronchi V, Cionini G. Cytogenetic activity of alicyclic and aromatic epoxides. Mutat res 85 (1981) 291-292.

31. Vainio $H$, Norppa $H$, Hemminki $K$, Sorsa M. Metabolism and genotoxicity of styrene. In: Snyder R, Parke DV, Kocsis J, Jollow DJ, Gibson GG, Witmer CM, ed. Biological reactive intermediates-II, part A. Plenum, New York, NY 1982, pp 257-274.
32. Vainio $H$, Pääkkönen $R$, Rönnholm $K$, Raunio V, Pelkonen O. A study on the mutagenic activity of styrene and styrene oxide. Scand j work environ health 3 (1976) $147-151$.

33. Voogd CE, van der Stel JJ, Jacobs JJJAA. The mutagenic action of aliphatic epoxides. Mutat res 89 (1981) 269-282.

34. Wade DR, Airy SC, Sinsheimer JE. Mutagenicity of aliphatic epoxides. Mutat res 58 (1978) 217-223.

35. Watabe T, Hiratsuka A, Aizawa T, Sawahata T, Ozawa N, Isobe M, Takabatake $\mathbf{E}$. Studies on metabolism and toxicity of styrene: IV 1-Vinylbenzene 3,4-oxide, a potent mutagen formed as a possible intermediate in the metabolism in vivo of styrene to 4-vinylphenol. Mutat res 93 (1982) $45-55$.

36. Watanabe $T$, Endo A, Sato $K$, Ohtsuki $T$, Miyasaka M, Koizumi A, Ikeda M. Mutagenic potential of styrene in man. Ind health 19 (1981) 37-45. 